\title{
Dose Frequency Code
}

National Cancer Institute

\section{Source}

National Cancer Institute. Dose Frequency Code. NCI Thesaurus. Code C93556.

A coded value specifying how often a dose is administered. 